تأثير كودهاى آلى اسيدهيوميك و اسيدآمينه بر رشد ميوههاى گوجهفرنكى گلخانهاى برداشت شده در جهار مرحله رشدى

مريم حقيقى "* و حجتاله نجفى'

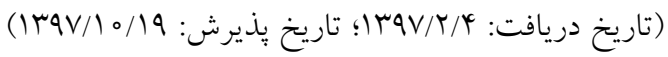

جكيده

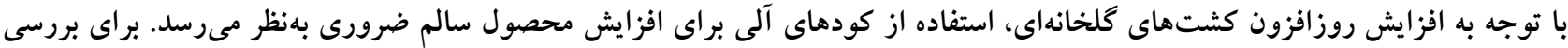

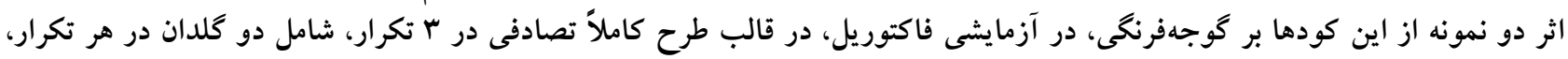

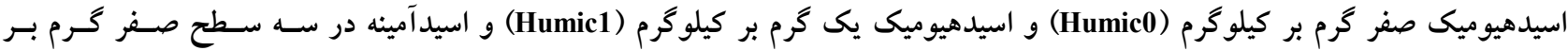

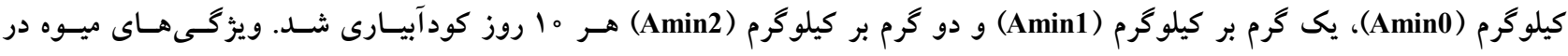

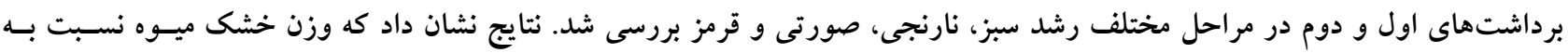

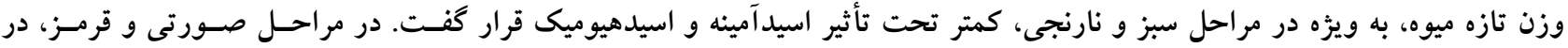

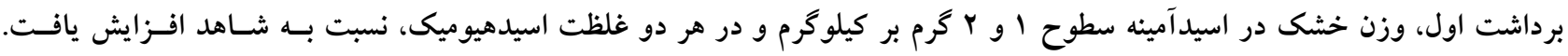

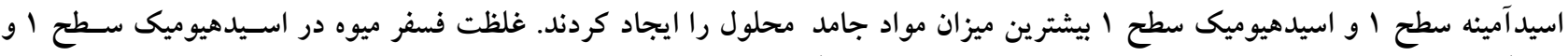

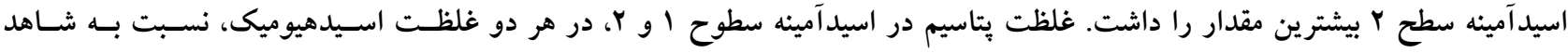

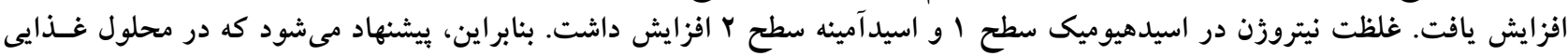

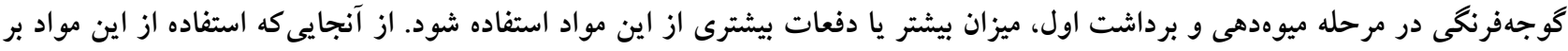

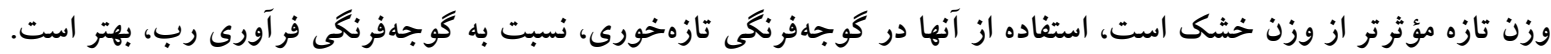

وازههاى كليدى: جذب عناصر غذايى، قطر ميوه، كود آلى، محصول آلى

كاربرد كودهاى شيميايى بهلحاظ آسيبهاى زيست محيطى يكى

مقدمه

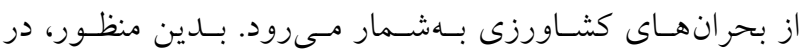

در كودياشىهاى سنتى، مقدارى از موادى كـهـ از راه خـاك و از

كشاورزى بايدار و آلىى، هـــف اصـلى، بـهـــاركيرى كودهـاى

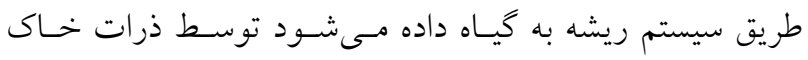

زيستى براى افزايش كمّى و كيفى محصولات كشاورزى اسـت فئ.

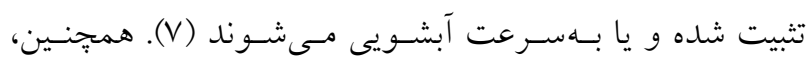

ا. كروه باغبانى، دانشكده كشاورزى، دانشخاه صنعتى اصفهان mhaghighi@iut.ac.ir :مسئول مكاتبات، بـت الكترونيكى" 


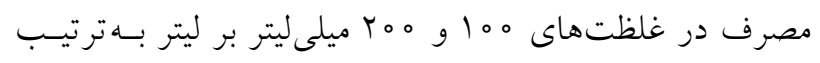

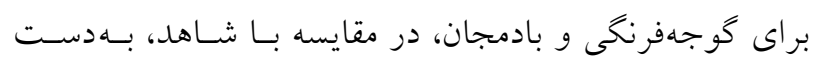
آمد. تحت تأثير اين تيمار رشد ريشه، مقدار عناصر برمصـرف و كممصرف تعداد كل هاى برداشتشده در هـر گيـاه افـزايش

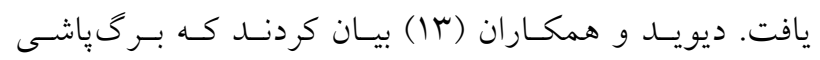
اسيدهيوميك، رشد گياهجههــاى گوجـهفرنخـى را بهبـود مسى

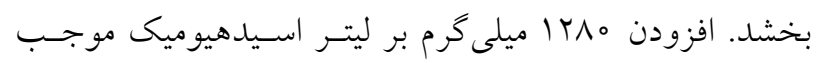

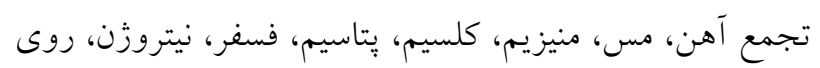

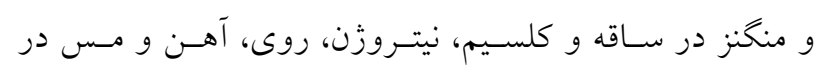
ريشهها شد. يكى ديخر از كودهاى آلى زيستى بلززراعى، اسيدهاى آمينـه

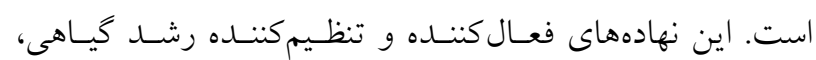

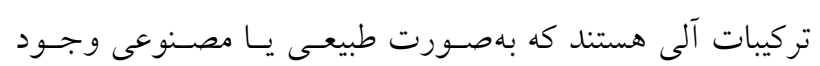

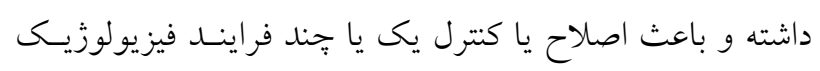

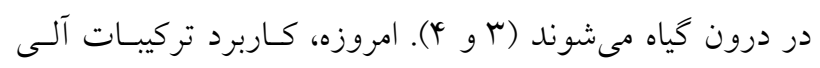
زيستى اسيدآمينه در بهبود رشد كياهان مورد توجه قـرار گرفتسه است كه دليل اين توجه، نقش اساسى اسيدهاى آمينه در حيـات جانــاران اسـت. ارزش اسـتفاده از فــــاوردههــاى زيسـتى بـا مجموعهاى از اسيدهاى آمينه آزاد در اين است كه بهدليل غنـاى

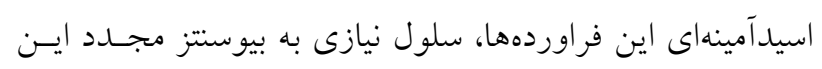

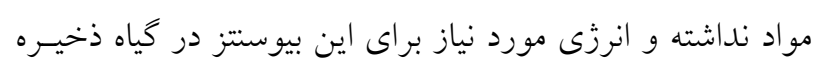
مىشود. اين فراوردهها با تأثير بر روند يروتئينسازى در سطوح

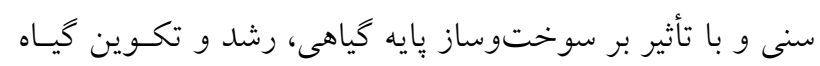
را منظم كرده و در مراحل مختلف رشد كارايى و كاربرد خاص خود را با كوددهى از طريق خاى و محلولياشى در اختيار گيـاه قرار مىدهند. در واقع، تغذيه بركى اسيدهاى آمينه آزاد مىتواند

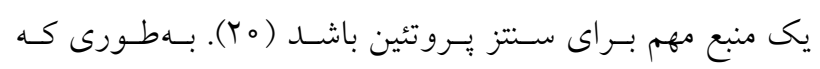
محمود و عليزاده (N) نشان دادند كه محلولياشى اسيدآمينه آزاد در ماشكى رقم كل سفيد (Vicia panonica) در شرايط ديــم، در مقايسه با تيمار شـاهد (بـدون محلـول ياشـى) موجـب افـزايش

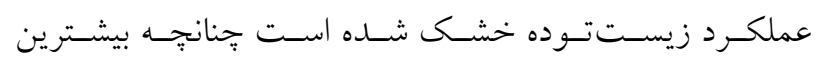
اثربخشى در افزايش عملكرد زيستتوده خشك مربوط به سـال
به كار كيرى كودهاى زيستى بهدليل سـامت محصـول و تجمـع

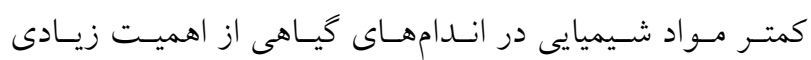

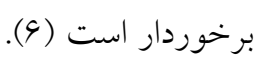

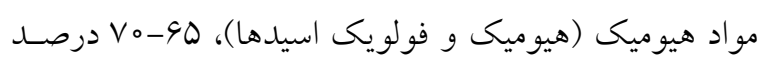
مواد آلى خـاك را تشـكيل مسىدهنــــ و موضـوع مهمسى بـراى يزّوهش در زمينههاى مختلف كشـاورزى مانــــ شـيمى خـاك، حاصلخيزى و فيزيولوزى گياه و علوم محيطى هستند زيــرا ايسن

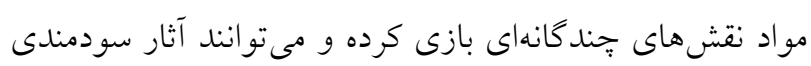

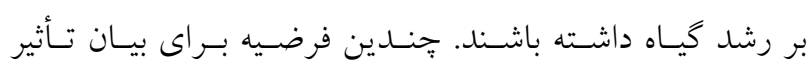
اسيدهيو ميك بيشنهاد شده است كه شامل تشكيل كميلكس بــين اسيدهيوميك و يونهاى معلنى، كاتاليز اسـيدهيوميك بـه آنـزيم هايى در كياه، تأثير اسيدهيوميك در تنفس و فتوسـنتز، تحريـى متابوليسم اسيدنو كلئيك و فعاليت هورمونى اسيدهيوميك هستند

سيميرين و ييلماز (11) بـا بررسى تـأثير اسـيدهيوميك و

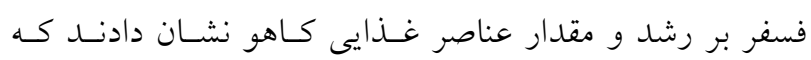
كاربرد اسيدهيوميك موجب بهبود عملكرد كاهو نمى شود؛ امـا

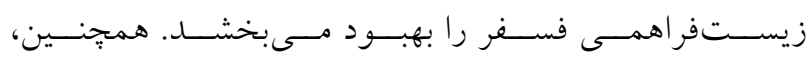
اسيدهيوميك، فسفر و برهمكنش آنها، مقدار نيتروزن كـاهو را افزايش داد. تأثير اسيدهيوميك بهصورت محلولياشى بركى و و كوددهى خاك بر عملكرد و كيفيت فلفل توسط كـاراكورت و همكاران (IV) مورد بررسى قرار كرفت. نتـايج نشـان داد كـه اسيدهيوميك بر سفتى بافت، طول و قطر ميـوه تـأثير نداشـت.

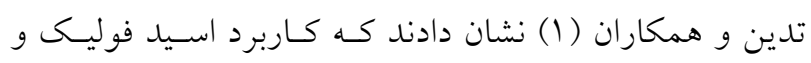

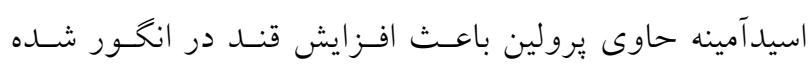

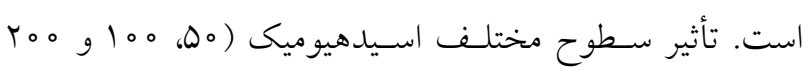

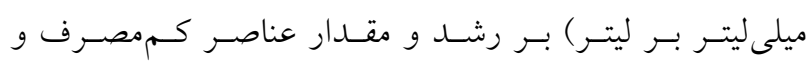

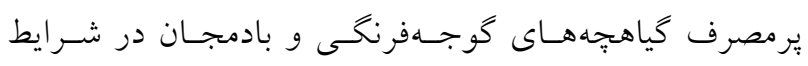
كلخانه توسط دارسون و همكـاران (Y) مـورد بررسـى قـرار كرفت. نتايج حاصل از ايسن يـزوهش نشـان داد كـه بيشـترين نسبت رشد ساقه و ريشه در غلظتهاى •ه و ه ه ا ميلسى ليتـر بر ليتر اسيدهيوميك و بيشترين مقدار عناصر برمصـرف و كـم 


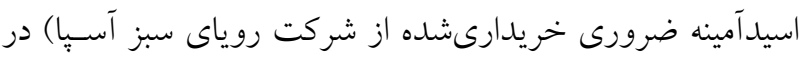
سه سطح (صفر، او ب گرم بر كيلو گرم) طراحسى شـــ تيمارهـا،

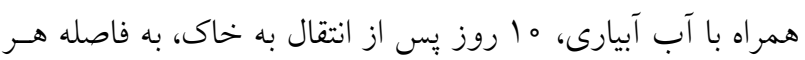
ها روز،، تا مرحله برداشت افـزوده شــند. خـاك مـورد اسـتفاده داراى بافت لوم سـيلتى، pH برابـر D

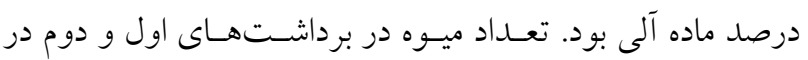
مر احل مختلف رشــ سـبز، نـارنجى، صـورتى و قرمـز شـمارش كُشته و صفات وزن تازه و خشك، قطر ميوه، مو اد جامـــ محلـول و سفتى بر طبق مراحل رشد ميوه اندازهيرى شدند. قطر ميسوه بـا كـوليس ديجيتـال (Mitutoyo Co., Japan)، سـفتى بافـت ميـوه

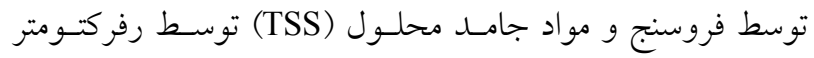
(PAL-1 Brix, Japan) آون Vo درجه سلسيوس خشك شدند. وزن تازه و خشك ميوهها با ترازوى ديجيتال اندازهيـــى شـــ. در بايـان آزمـايش، كياهـان

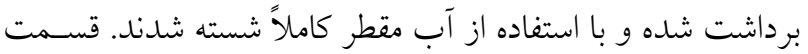

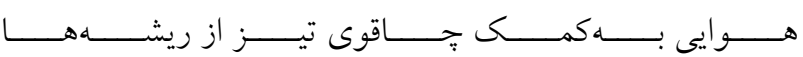

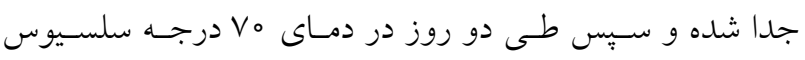

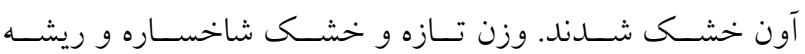
به كمك ترازوى ديجيتال اندازهكيرى شد. در بايان آزمايش، ميـزان

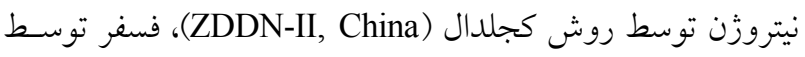

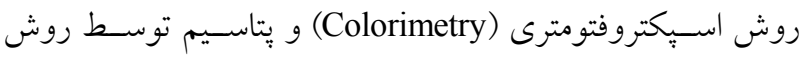

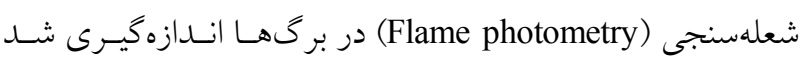

دادهها در نرم|فزار MS Excel طبقدبنـدى شـــه و بــا برنامـهـ آمارى Statistix 8 تجزيه آمارى شدند و مقايسه ميانخين دادههـا بهكمى آزمون LSD در سطح احتمال ه. انجام شد.

\section{نتايج و بحث}

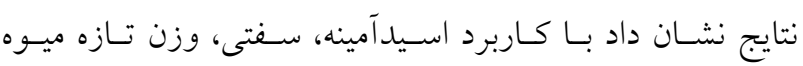
صورتى، وزن خشك ميوه نارنجى، وزن تـازه و خشـك ميـوه و

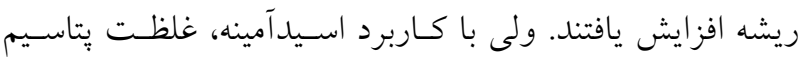

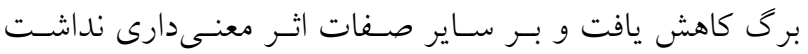

اول بوده است. همجنين، محلول يڤاشَى تركيبـات اسـيدآمينه بـر

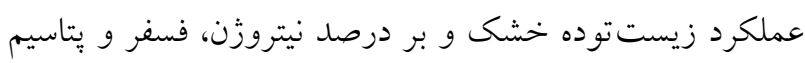

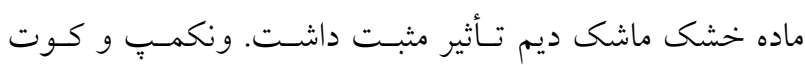

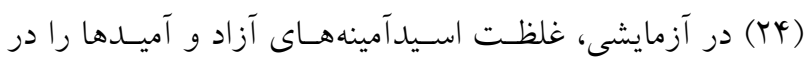
ذرت مورد بررسى قرار داده و مشاهده كردند كه كـاربرد مقــدار

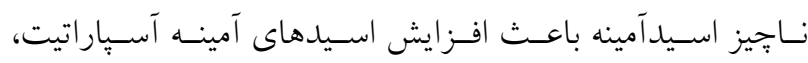

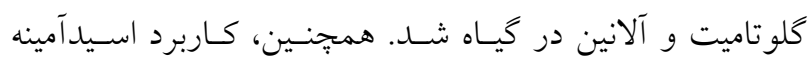
يرولين بر اندامهاى زايشى باعث افزايش بارورى و متابوليسم و

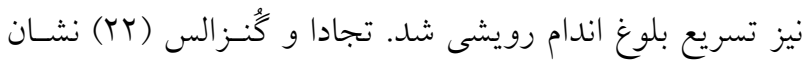

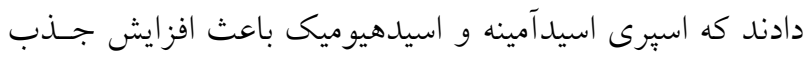
فسفر، نيتروزن و بتاسيم شــه و همجنسين باعت توليــ بيشـتر كربوهيدراتهاى محلـول در سيستم ريشـهاى مارجوبـهـ شـــه

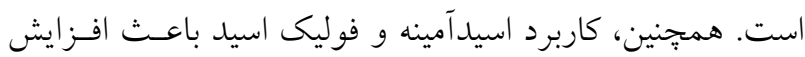
قند در انكور شده است (1).

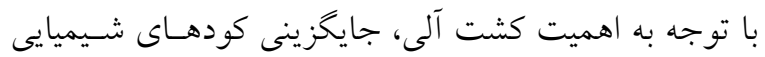

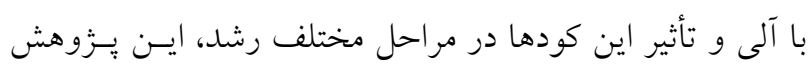

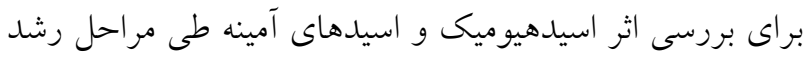
ميوه كوجهفرنكى صورت كرفت.

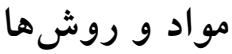

بذرهاى كوجسهرنخـى (Lycopersicon esculentum var. Foria)

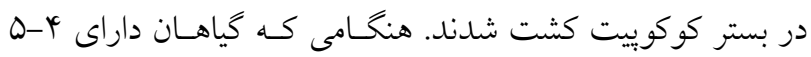
برى حقيقى شدند به كلدانهاى ثل ليترى حاوى خاك در كلخانسه

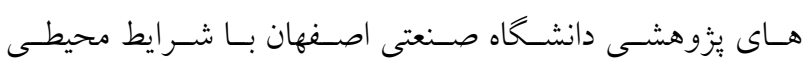
كترلشده شامل ميانخين دماى روزانه بـ

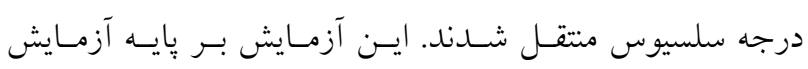

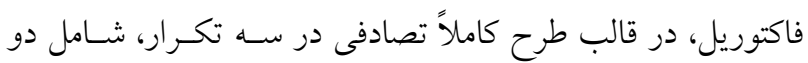

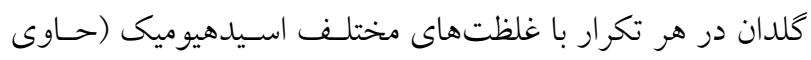

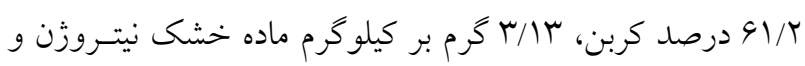

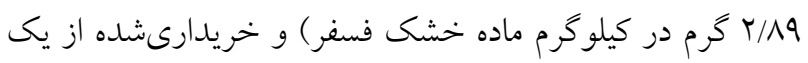
شركت جينى (Dalian Yano Agriculture Co., Dalian, China)

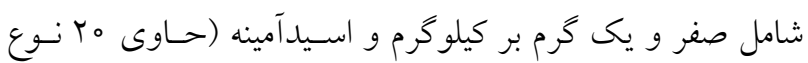


صورتى و قرمز ميوه صورت مى گيـرد. بنـابراين، بـا توجـهـ بـهـ

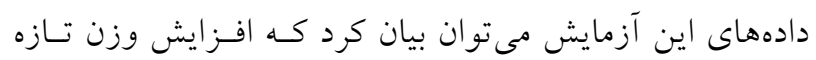

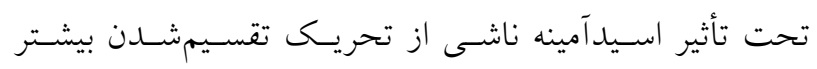

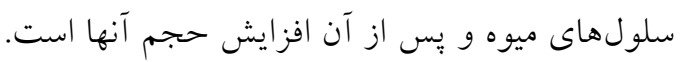
وزن خشك ميوه نسبت به وزن تازه ميوه، به ويزه در مرحله سبز و نارنجى، كمتر تحت تأثير اسيدآمينه و اسيدهيوميك قـرار كرفت. در مرحله صورتى و قرمز، در برداشت اول، وزن خشك

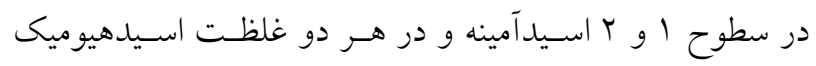
نسبت به اسيدآمينه صفر و اسيدهيوميك صفر افزايش داشت. اما در برداشت دوم تنها غلظـت زيـاد اسـيدآمينه، يعنسى اسـيدآمينه سطح ז، در حضور و عدم حضور اسيدهيوميك در مرحله قرمز باعث افزايش وزن خشك شد (شكل r). بهنظر مىرسد با رسيدكى ميوه و به ويـرّه در برداشـت دوم

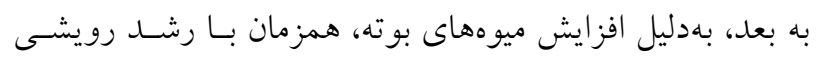
ميوه غلظت و ميـزان بيشـترى از اسـيدهيوميك و اسـيدآمينه بـر رشد ميوه مؤثر است. بنابراين بيشنهاد مىشود در محلول غذايى كوجهفرنكخى، در مرحله ميوهدهى و برداشت اول، ميـزان بيشـتر يا دفعات بيشترى از اين مواد استفاده شود. بـهنظـر مسىرســ از

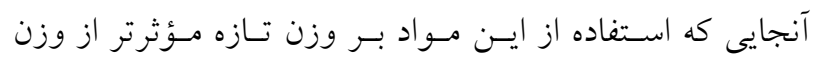

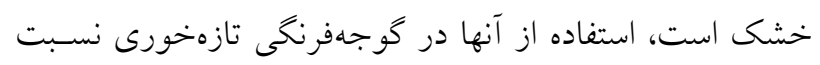
به گوجهفرنكى فراورى رب بيشتر قابل توصيه است.

\section{اثر برهم كنش اسيدآمينه و اسيدهيوميك بـر قطـر ميسوه طـى جهار مرحله رشد ميوه} نتايج مقايسه ميانخين قطر ميوه نشان مسىدهــ كـه قطر ميـوه در برداشت اول و مراحسل اول رشـد ميـوه (سـبز و نـارنجى) بيشـتر تحت تأثير اسيدهيوميك و اسيدآمينه قرار كرفته اسـت. بـهــورى كه بيشترين افزايش در مرحلـه سـبز در برداشـت اول بـا افـزودن اسيدآمينه سطح Y و هر دو غلظت اسيدهيوميك حاصل شد. قطر ميوه در مرحله نارنجى توسط اسيدآمينه سـطوح ا و r در هـر دو غلظت اسيدهيوميك افزايش معنى دارى داشت. روند مشخصى در ساير غلظتها و مراحل ديده نشد. اخر جهه افزايش معنسىدار قطر
(بنابراين از آوردن دادهها به دليل حجم زيـاد دادههـا خــوددارى شد). اثر ساده اسيدهيوميك بر هيجيك از صفات معنى دار نبـود (دادهها نشان داده نشده است).

اثر برهم كنش اسيدآمينه و اسيدهيوميك بر وزن تازه و خشك ميوه

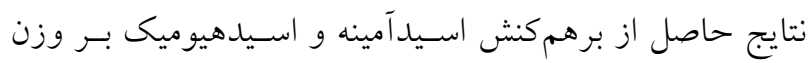

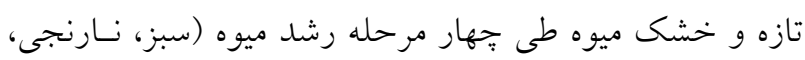

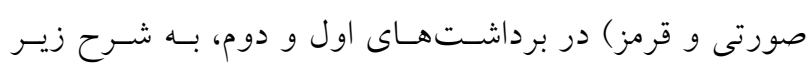

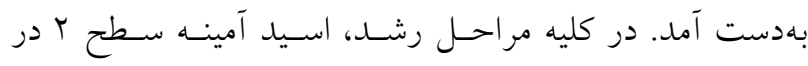
حضور و عدم حضور اسيدهيوميك باعث افزايش وزن تـازه،

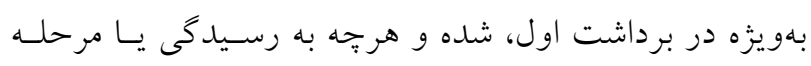

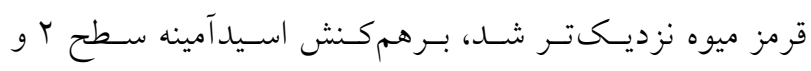

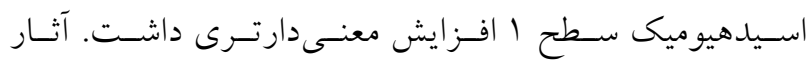

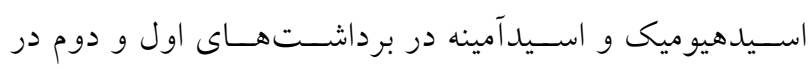

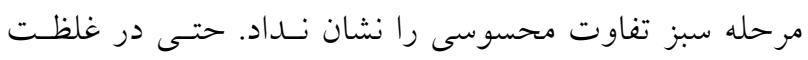

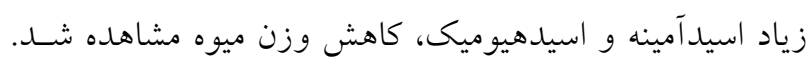

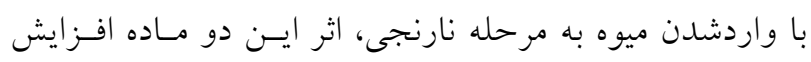

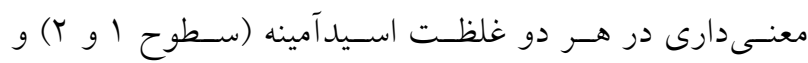

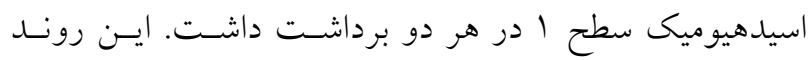
افزايش وزن در مرحله صورتى كمى توقف داشت بهطورى كه

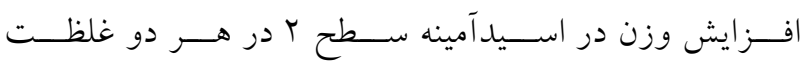
اسيدهيوميك در هر دو زمان برداشت ديــده شـــــ و در مرحلـه

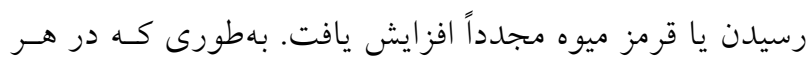

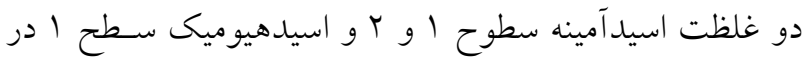
برداشت اول و در هر دو غلظت اسيدهيوميك در برداشت دوم نسبت به تيمار شاهد افزايش وزن ديده شد. مقايسـه تغييـرات

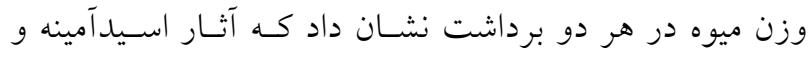

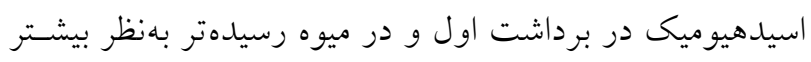

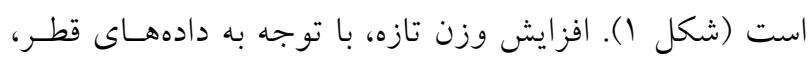
بهنظر مىرسد به افزايش تقسيم سلولى و قطر در مراحل رشد

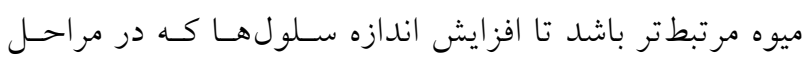



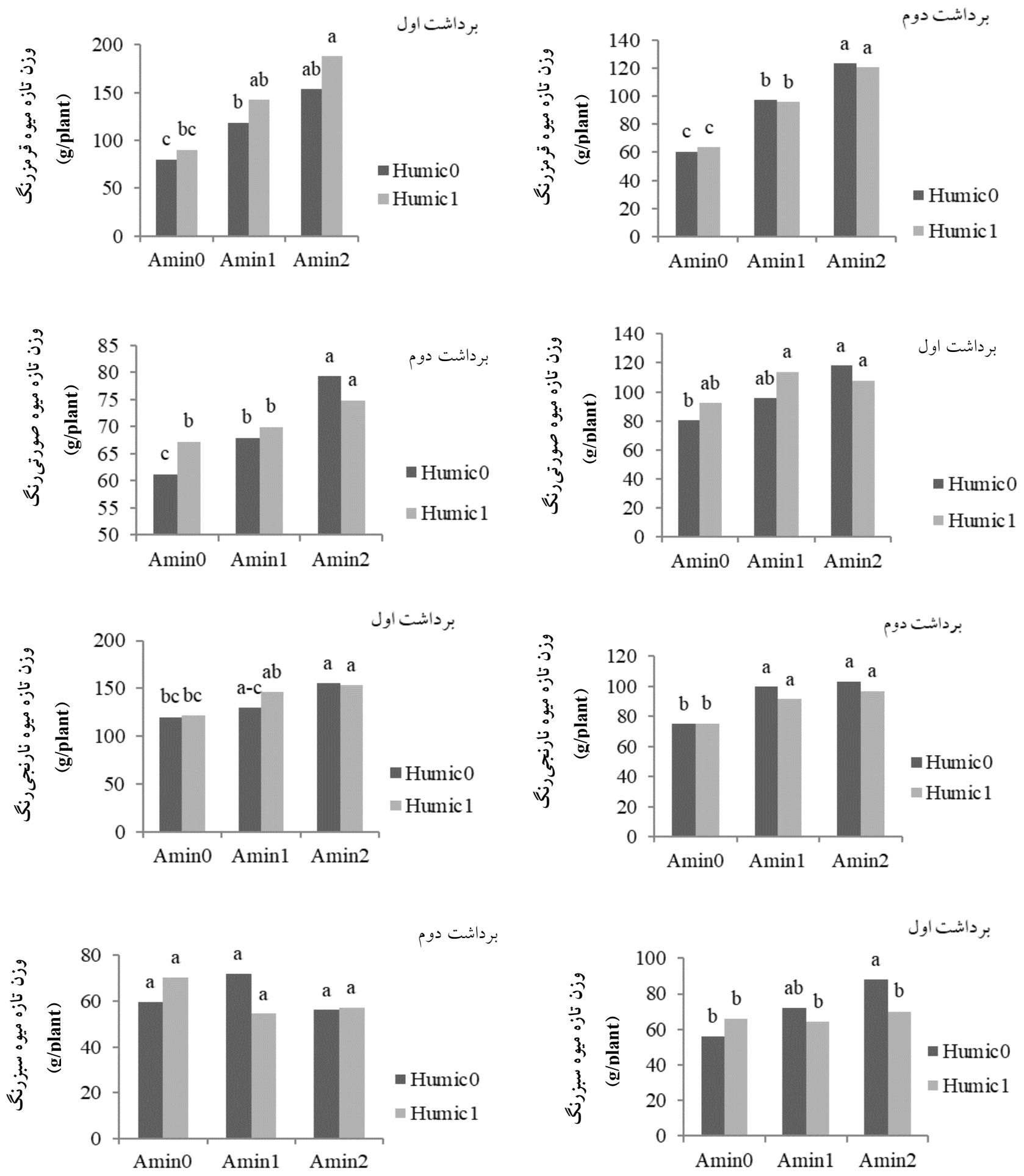

شكل ا. اثر برهم كنش اسيدآمينه و اسيدهيوميك بر وزن تازه ميوه در جهار مرحله در برداشتهاى اول و دوم (Amin0 شاهد، Amin1 يك

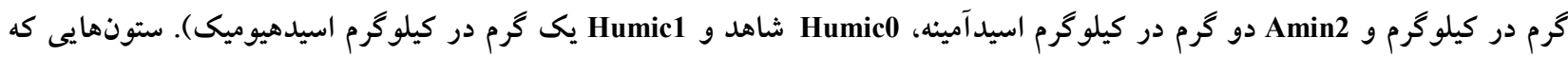
در يك حرف متفاوت هستند داراى تفاوت معنىدار در سطح ه٪ بر اساس آزمون LSD هستند. 

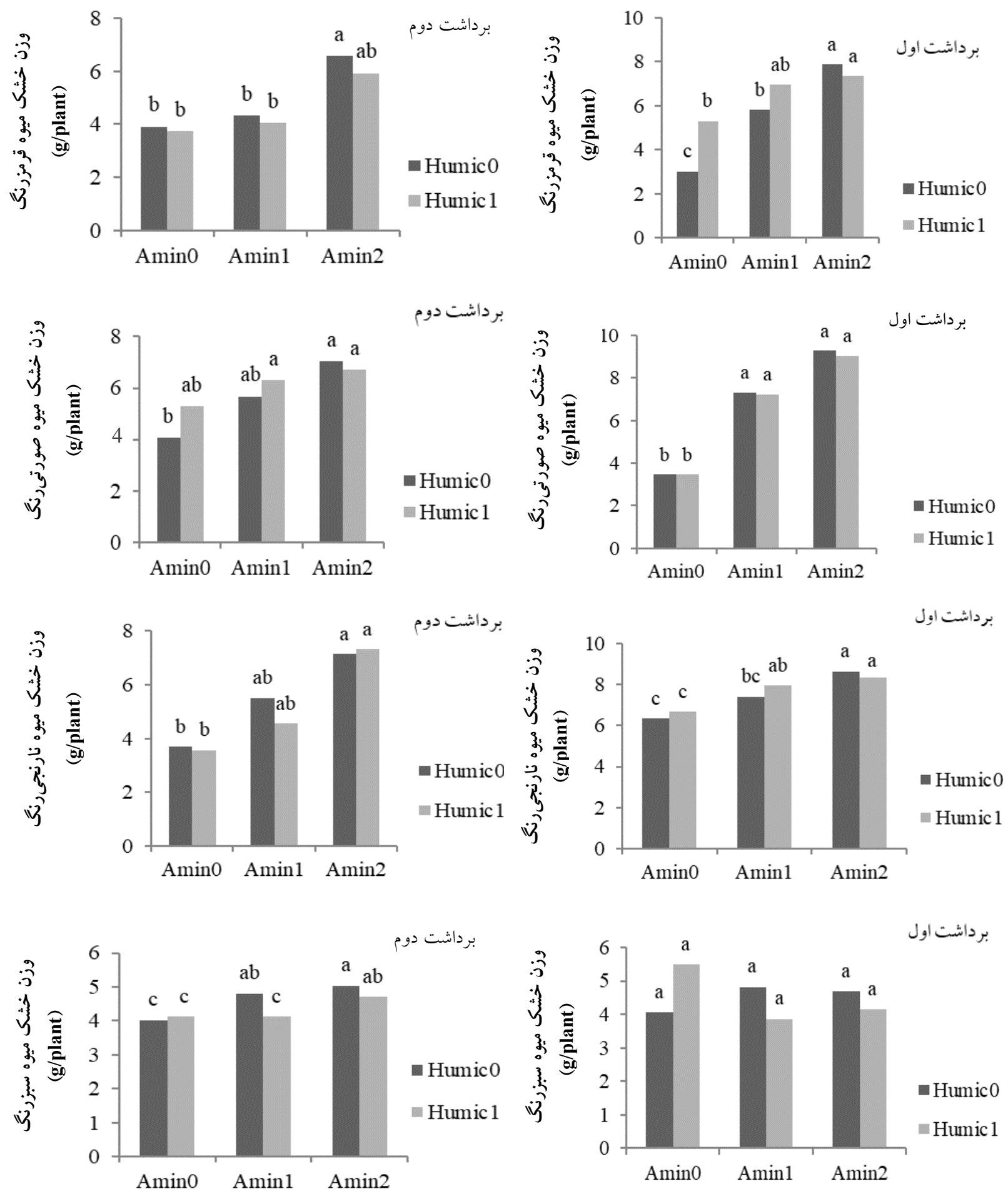

شكل r. اثر برهم كنش اسيدآمينه و اسيدهيوميك بر وزن خشك ميوه در جهار مرحله در برداشتهاى اول و دوم. Amin0 Aاهد، Amin1 A يك گرم در كيلو گرم و Amin2 دو گرم در كيلو گرم اسيدآمينه، Humic0 شاهد و Humic1 يك گرم در كيلو گرم اسيدهيوميك). ستونهايى كه در يك حرف متفاوت هستند داراى تفاوت معنىدار در سطح ه٪ بر اساس آزمون LSD هستند. 
آمونياكى مى شود و همجنين نيتروزن در رشد، تقسيم سـلولى و

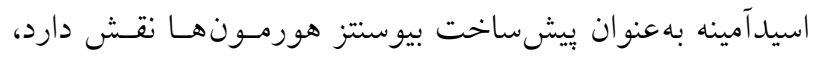

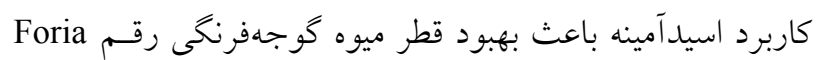

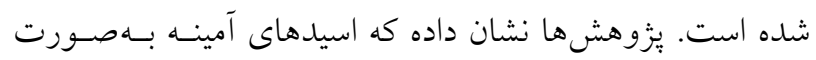
مستقيم و غيرمستقيم بر فعاليتهاى فيزيولوزيك، رشدونمو كياه

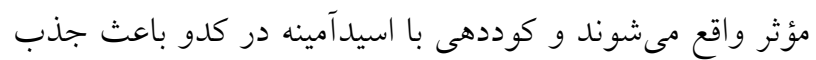

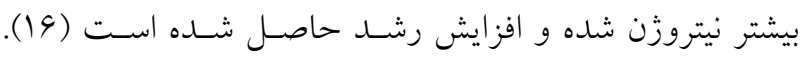

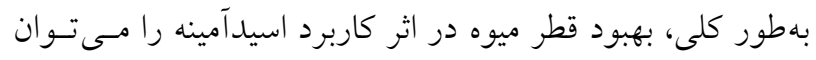

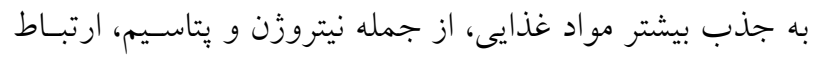

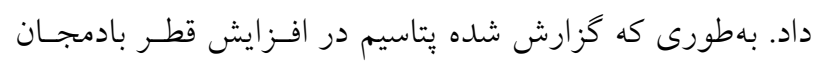

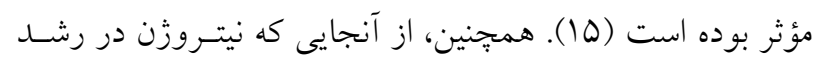

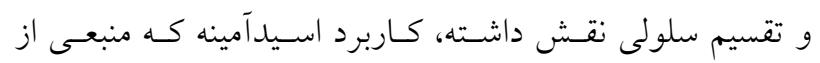

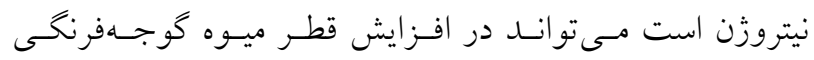
تأثير كذار باشد. همجنين، از آنجايى كه اسيدهاى آمينه، از جمله فئه

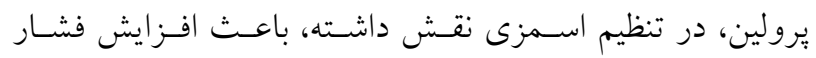

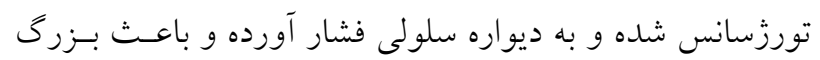

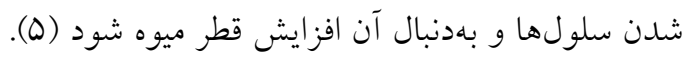

اثر برهم كنش اسيدآمينه و اسيدهيوميك بر درصد مواد جامسـد محلول اسيدآمينه سطح ا و اسيدهيوميك سطح ' بيشترين ميـزان مـواد

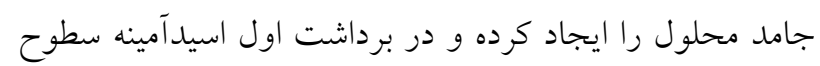
او Y بر هر دو غلظت اسيدهيوميك باعث افزايش مواد جامسـ

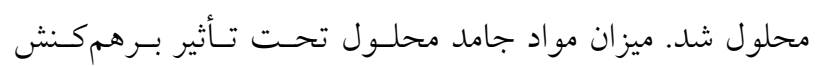

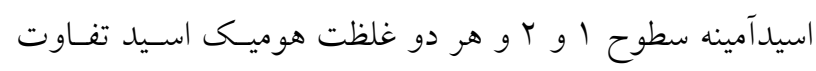
معنى دارى نداشت (شكل كأl). بهوطور كلى، كاربرد اسيدهيوميك همر اه با اسيدآمينه نسبت بـهـ

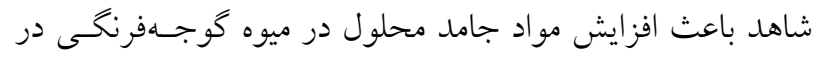

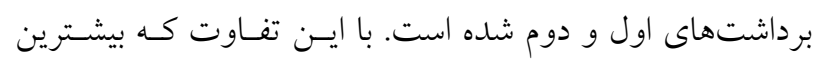

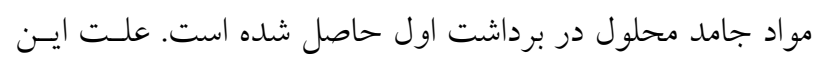

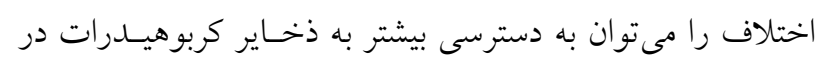

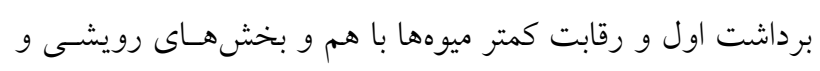

ميوه در تيمار اسيدآمينه سطح |، اسيدهيوميك سطح ا در مرحله

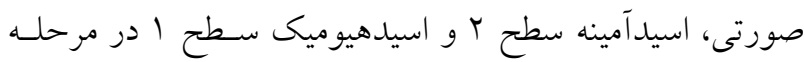
قرمز مشاهده شد (شكل س) (ب). بهةطور كلى، كاربرد اسيدآمينه، همراه با اسيدهيوميك، باعـث

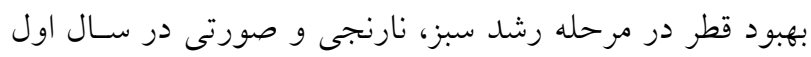

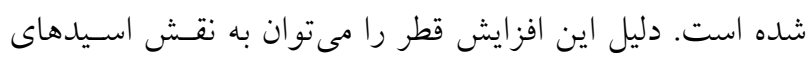

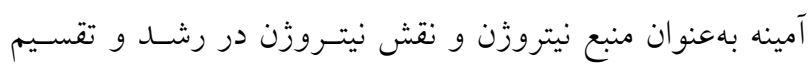

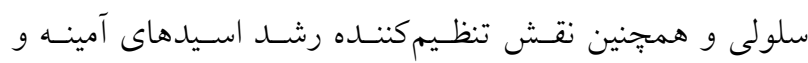

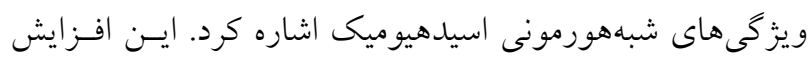

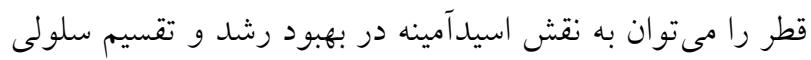

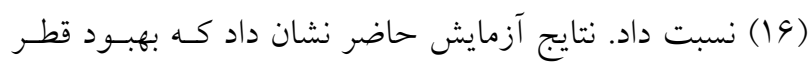

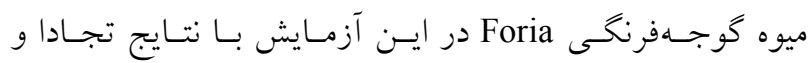

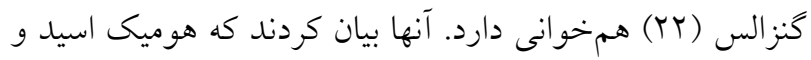

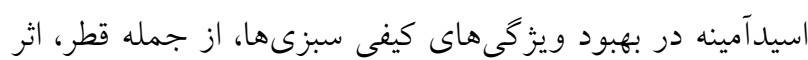

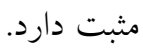
نتايج حاصل از اين يزوهش با نتايج كاراكورت و همكـاران همخ (IV)

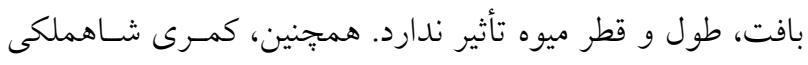

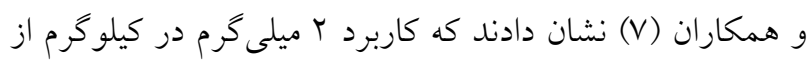

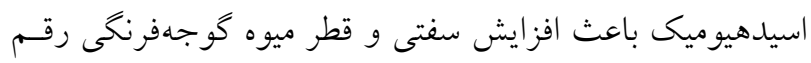

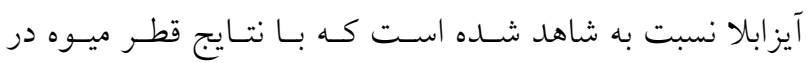

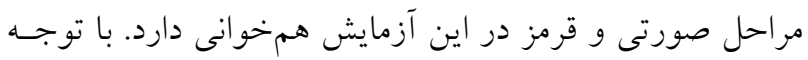

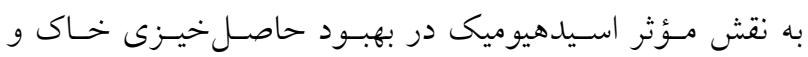

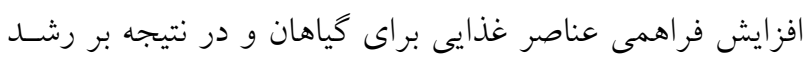

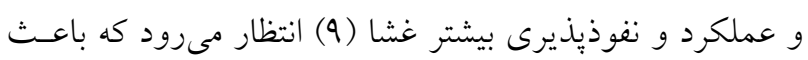
بهبود كيفيـت و عملكـرد ميـوه شـود. احتمـال دارد در اسـتفاده بيشتر، بهويزه از مرحله ميوهدهى به بعد، اثر خود را بهتـر نشـان دهد. بهطورى كه كاراكورت و همكاران (IV) نشـان دادنــ كـهـ

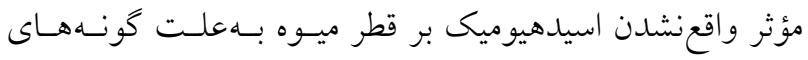

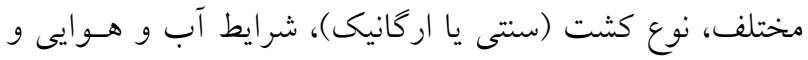
منبع اسيدهيوميك است. تئ. از آنجايى كه نيتـروزن بـه فـرم اسـيدآَمينه مـانع از سـمْيت 

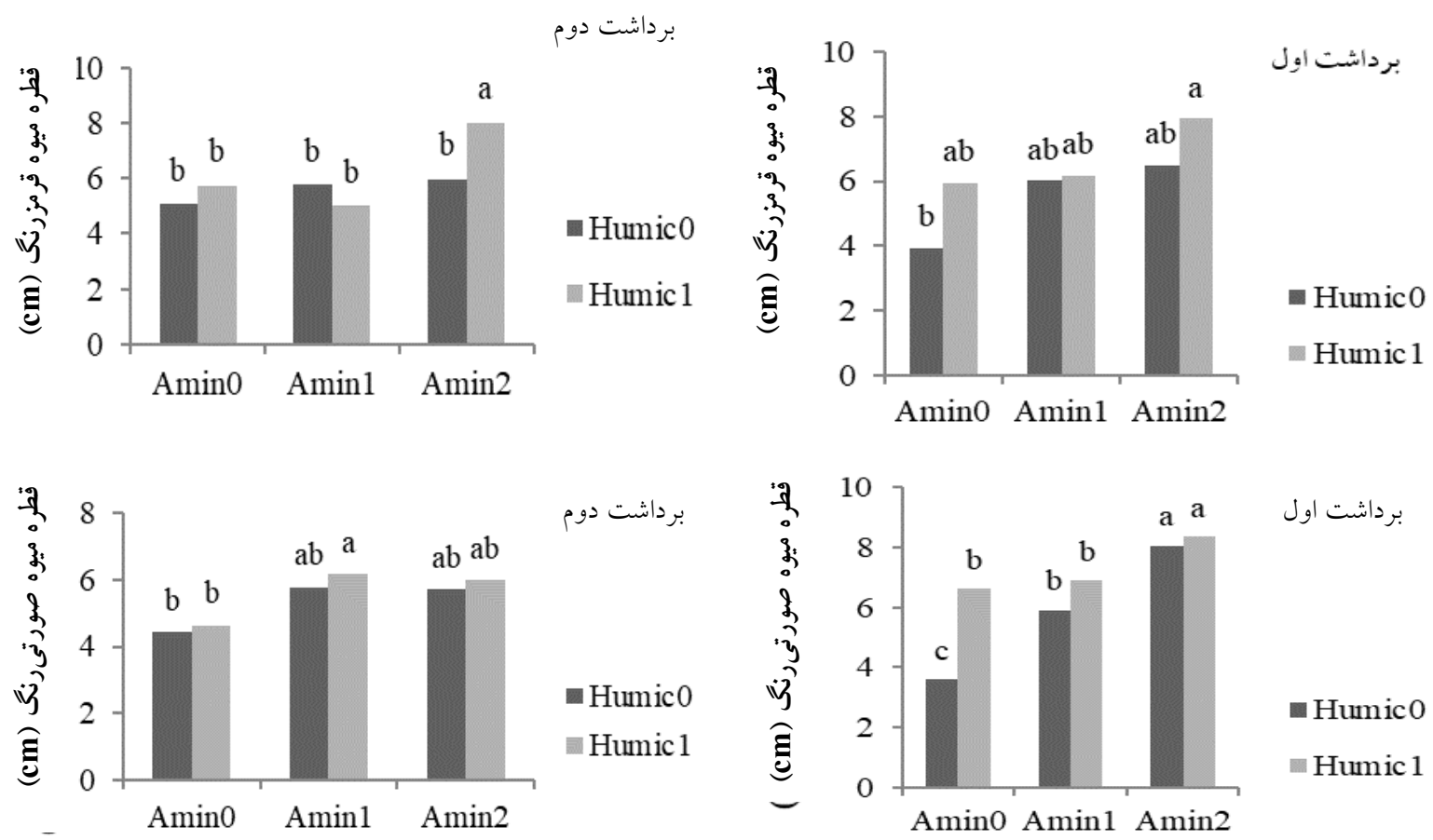

- Humic0

Humic 1
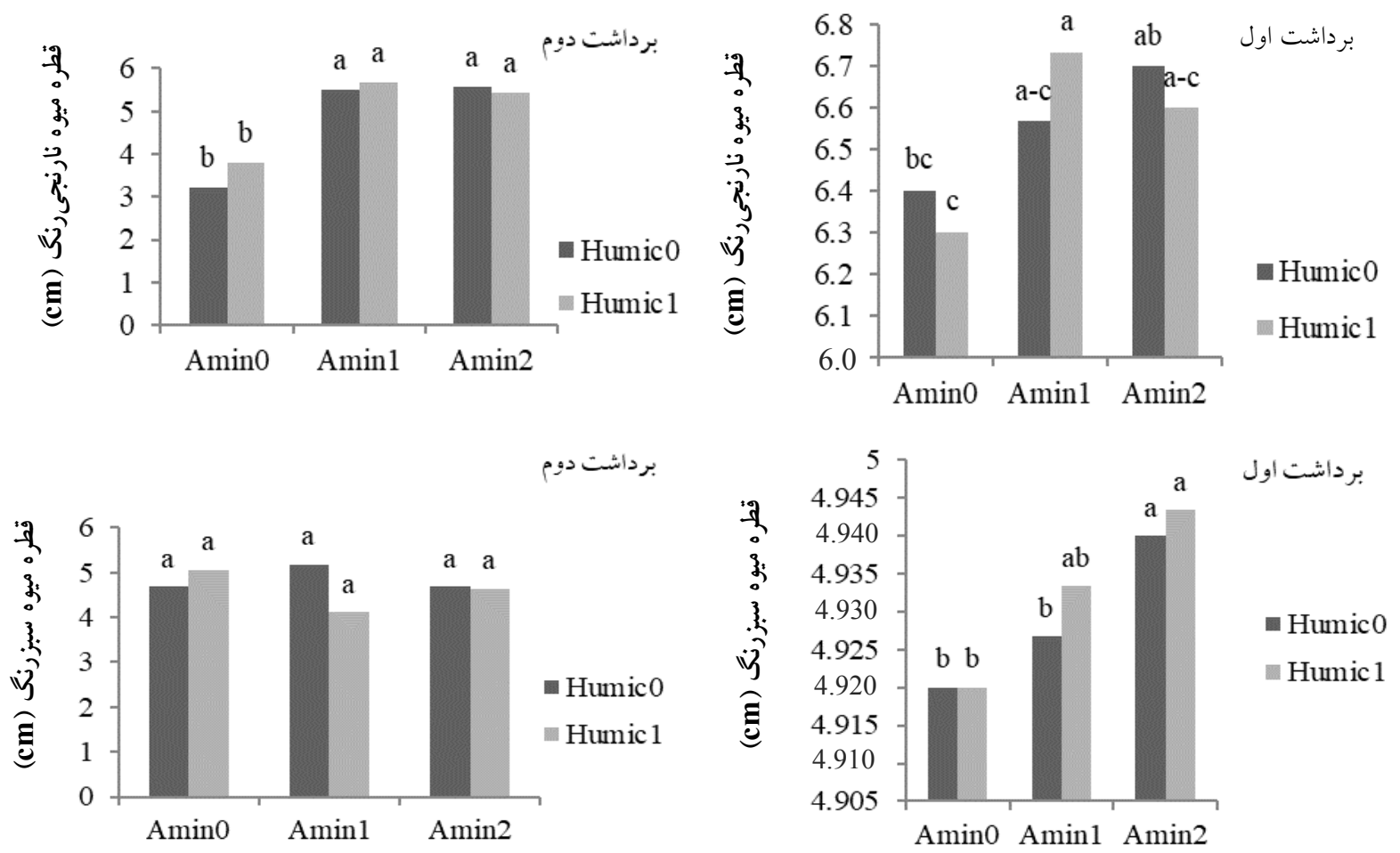

شكل س. اثر برهم كنش اسيد آمينه و اسيدهيوميك بر قطر ميوه در جهار مرحله در برداشتهاى اول و دوم. (Amin0 شاهد، Amin1 يك گرم در كيلو رم و Amin2 دو گرم در كيلوگرم اسيدآمينه، Humic0 شاهد و Humic1 يك گرم در كيلوگرم اسيدهيوميك). ستونهايى كه در يك حرف متفاوت هستند داراى تفاوت معنى دار در سطح ه٪٪ بر اساس آزمون LSD هستند. 

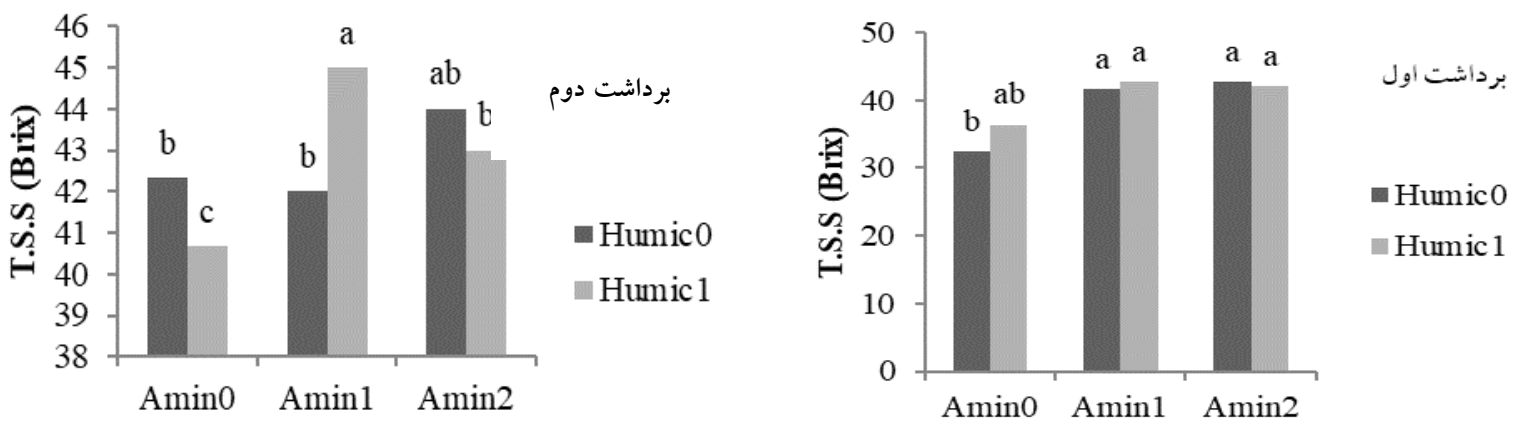

شكل ץ. اثر برهم كنش اسيدآمينه و اسيدهيوميك بر مواد جامد محلول ميوه در برداشتهاى اول و دوم (Amin0 شاهد، Amin1 يك كرم در

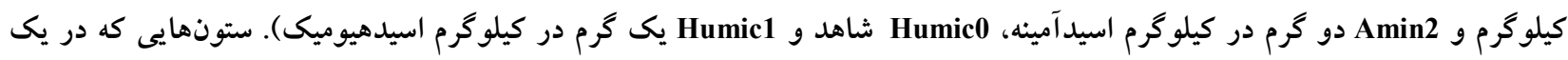

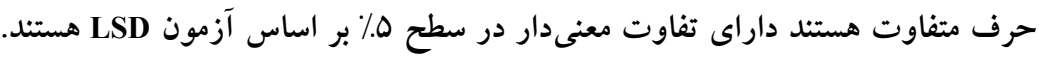

اسيدآمينه مربوط دانست. بهطورى كـه فـاتن و همكـاران (19) نشان دادند كه محلول باشى با اسيدآمينه باعـث افـزايش جـــب فئب فسفر در كدو شده است. زمانى كه ميزان فسفر در سيتويلاسم تا

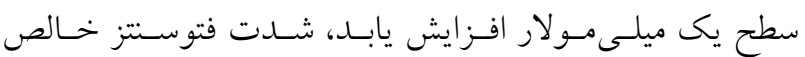

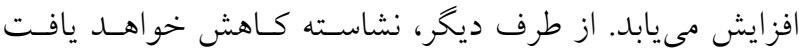

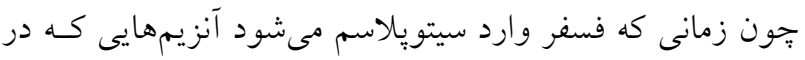
ساخت نشاسته دخالت دارند جلوى فعاليت آنها كرفته مى شئسود و در نتيجه ميزان قند افزايش مىيابد (ه).

اثر برهم كنش اسيدآمينه و اسيدهيوميك بر سفتى ميوه

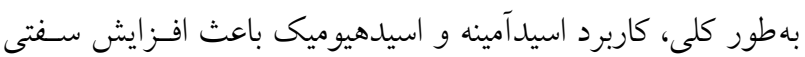
ميوه كوجهفرنكى، بهويزه در برداشت اول شده است (شكل هاه).

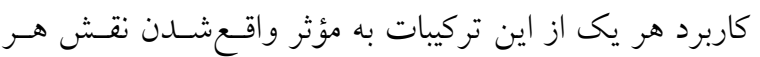

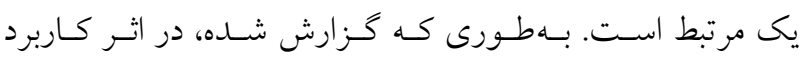

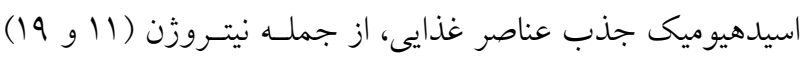

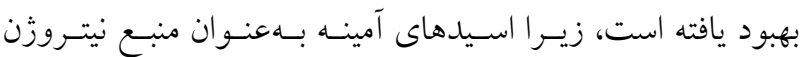

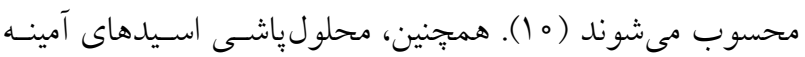

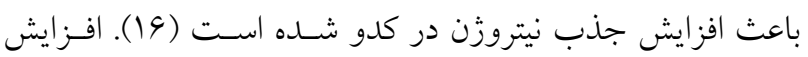

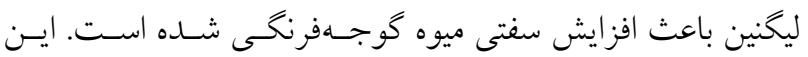
افزايش سفتى با غلظت مناسب اسيدهيوميك هب ميلى ليتر در ليتر

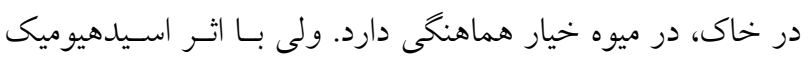

زايشى نسبت داد. همجنين، با توجه به جنبـه و هــدف از كـاربرد

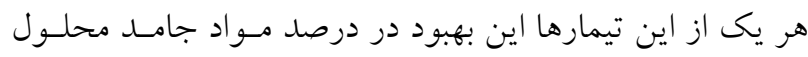
بهدست آمده است. از طرفى، كاربرد اسيدهاى آمينه كه بهعنوان

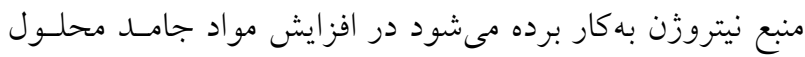

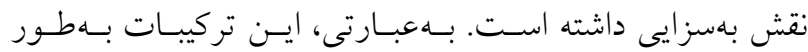
غيرمستقيم با افزايش جذب فسفر، كه در رسيدن و افزايش قنـــ بمواسطه غيرفعالشدن آنزيمهاى سنتز نشاسته و افزايش فتوسنتز خالص دارد (Q)، باعث افزايش درصد مواد جامد محلـول شــده

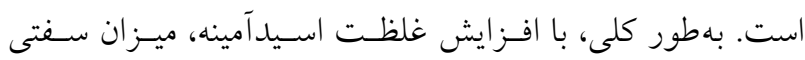

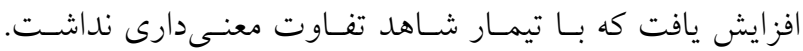

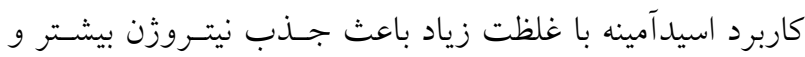

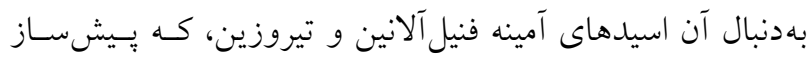

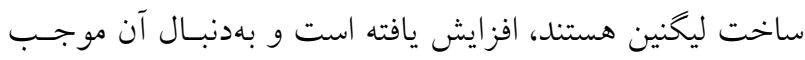

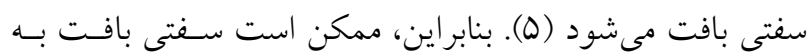

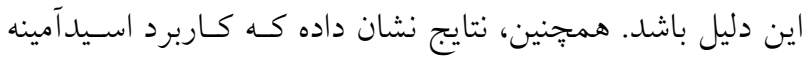

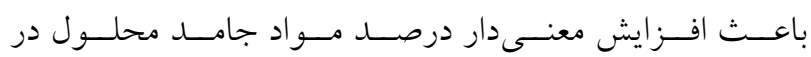
برداشتهاى اول و دوم شده است. در حقيقت، دسترسى گياه به

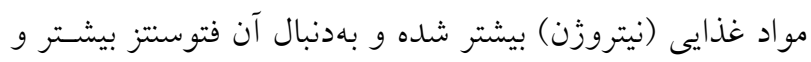

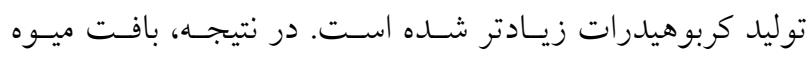

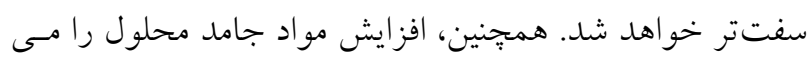
توان بهطور غيرمستقيم به جذب بيشتر عنصـر فسـفر بـا اعمـال 


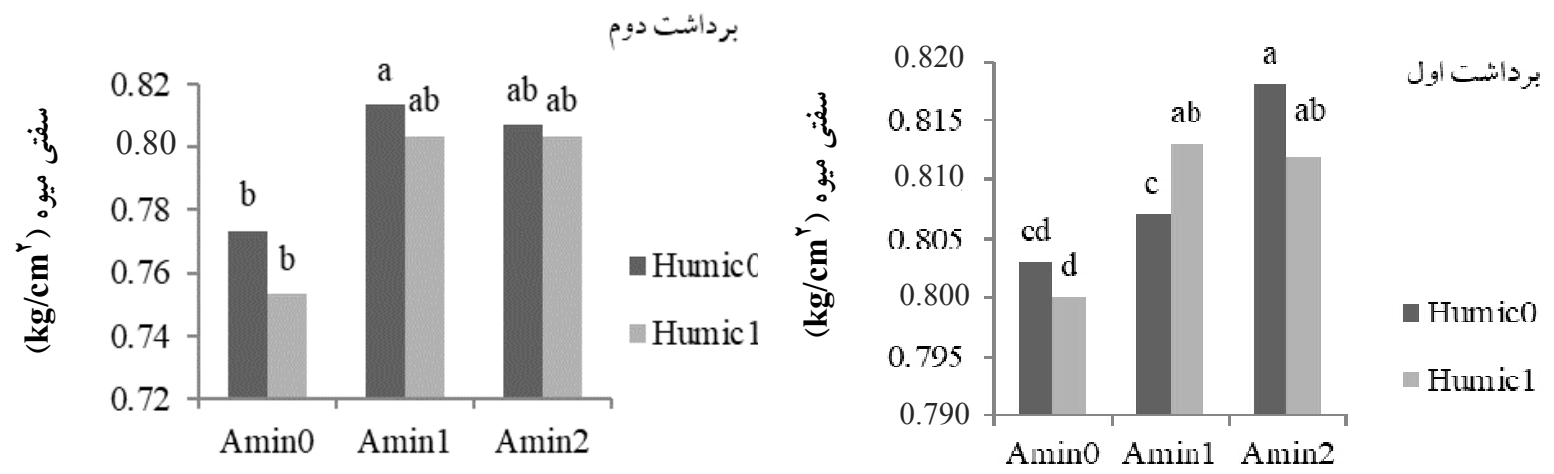

شكل ه. اثر برهم كنش اسيدآمينه و اسيدهيوميك بر سفتى ميوه در برداشتهاى اول و دوم (Amin0 شاهد، Amin1 يك گرم در كيلوگرم و

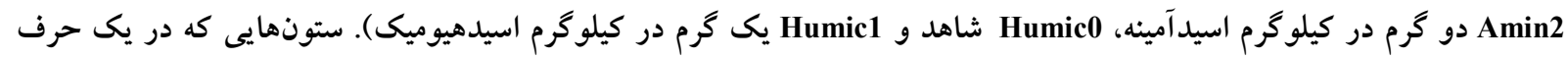

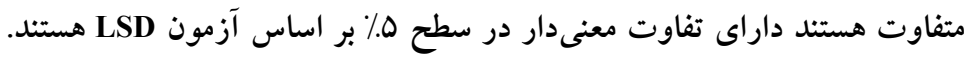
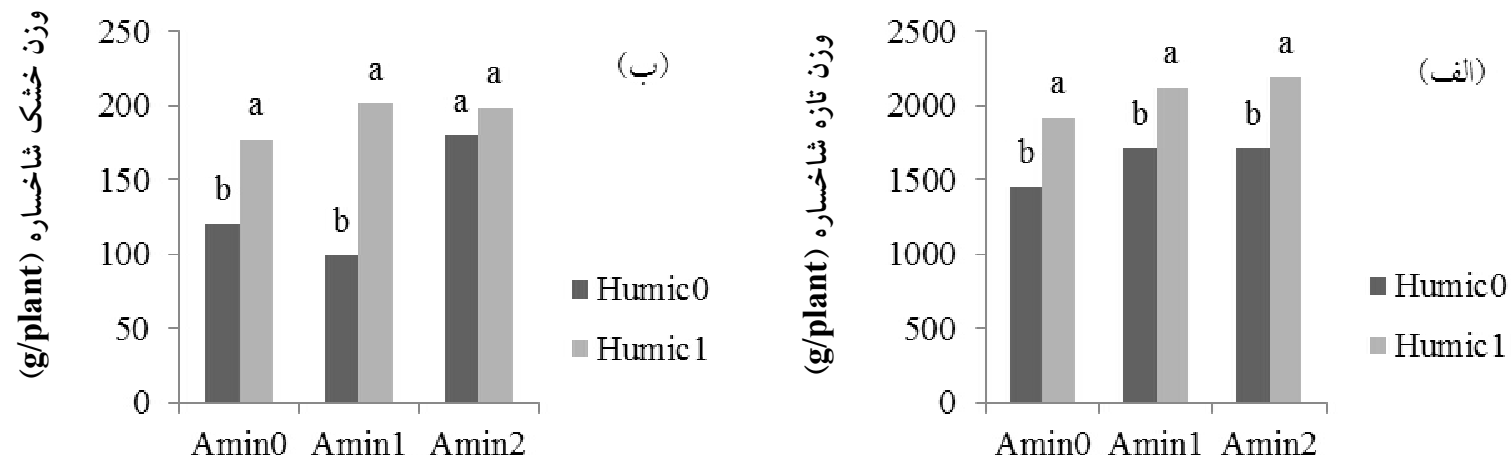

شكل צ. اثر برهم كنش اسيدآمينه و اسيدهيوميك بر: الف) وزن تازه شاخساره و ب) وزن خشك شاخساره در برداشت دوم. (Amin0 شاهد،

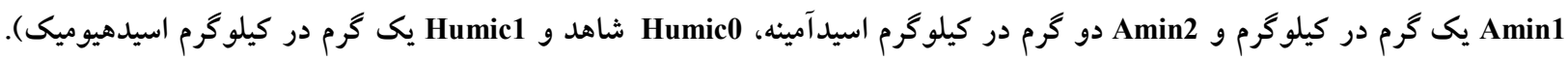

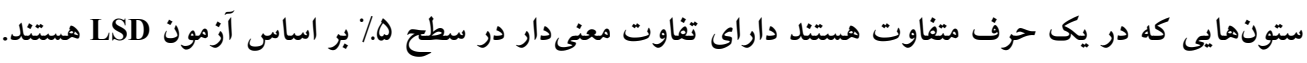

بر سفتى بافت فلفل كه تفاوت معنسىدارى نداشـت هـم خــوانى اسيدآمينه افزايش يافت (شكل 9).

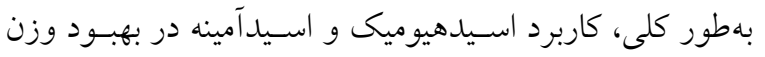

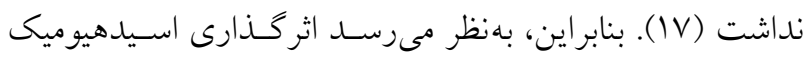

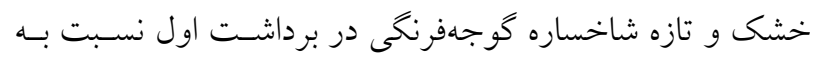

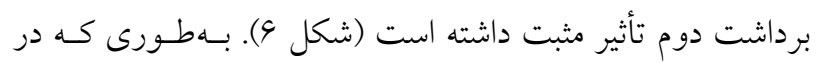

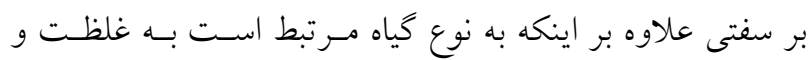

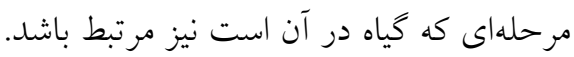

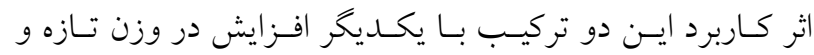
خشك بيشتر مشاهده شده است. اين نتايج با يافتهــاى دورسـون

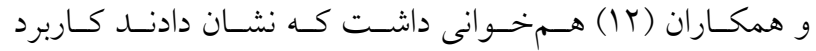
اثر برهم كنش اسيدآمينه و اسيدهيوميك بر وزن تازه و خشك اسيدهيوميك با غلظت هاى 0ه و 0 0 و ميلى ليتر در ليتر بـهترتيـب سبب افزايش وزن شاخسـاره در گوجسهرفنحى و بادمجـان شــه

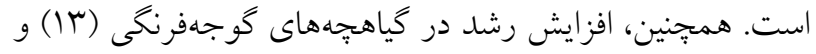
شاخساره نتايج حاصل از برهمكنش اسيدآمينه و اسيدهيوميك بر وزن تازه

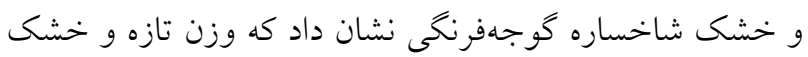

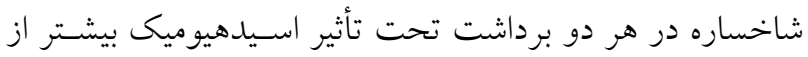



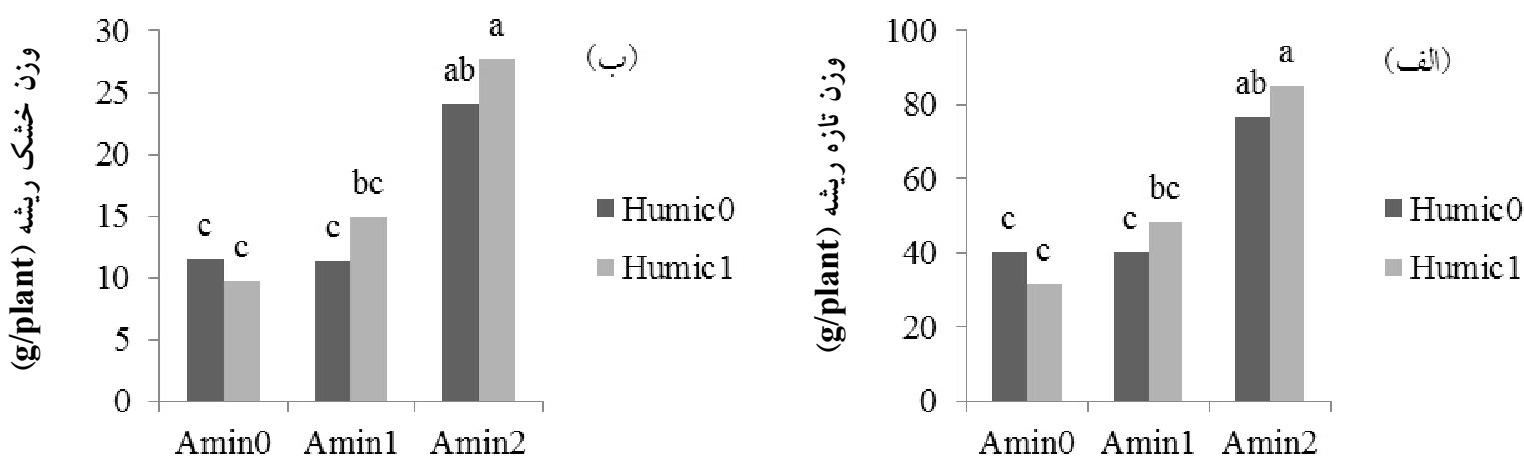

شكل V. اثر برهم كنش اسيد آمينه و اسيدهيوميك بر: الف) وزن تازه ريشه و ب) وزن خشك ريشه در برداشت دوم (Amin0 شاهد، Amin1 يك گرم در كيلو گرم و Amin2 دو گرم در كيلو گرم اسيدآمينه، Humic0 شاهد و Humic1 يك گرم در كيلو گرم اسيدهيوميك). ستونهايى كه در يك حرف متفاوت هستند داراى تفاوت معنىدار در سطح ه٪ بر اساس آزمون LSD هستند.

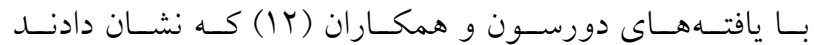
اسـيدهيوميك باعـث افـزايش وزن تــازه و خشـك ريشـهـ در كوجهفرنكى و بادمجان شده است، همخوانى داشت. همجنــين، افزودن اين ماده آلى به خاك باعث افزايش ريشههـاى جـانبى و سهولت جذب عناصر يرمصرف و كممصرف مىشود.

اثر برهم كنش اسيدآمينه و اسيدهيوميك بر جـذب يـونهـاى يتاسيم، فسفر و نيتروزن غلظت فسفر در تيمارهـاى اسـيدهيوميك سـطح ا و اسـيدآمينه سطح ب بيشترين مقدار را داشت. غلظـت يتاسـيم در اسـيد آمينه سطوح ا و r در هر دو غلظت اسيدهيوميك نسبت بـه شـاهد افزايش معنسىدارى داشـت. غلظـت نيتـروزن در اسـيدهيوميك

سطح ا و اسيدآمينه سطح ب افزايش يافت (شكل ^). بهطور كلى، كاربرد تركيبات اسيدهيوميك و اسيدهاى آمينـه

باعث تغييرات جزيى در افزايش جذب عناصر غذايى، از جملـه نيتروزن، فسفر و پِاسيم، شده است. در كودياشى سنتى، مقدارى از موادى كه از راه خاك و سيستم ريشه بــه گيـاه داده مسى شـود توسط ذرات خاى تثبيت شده و يا بهسرعت آبشويى مىشـوند. درحالى كه گزارش شده كه كاربرد اسيدهيوميك باعث افزايش وزن تازه و خشك ريشه و شاخساره گوجسهفرنخى در شـرايط

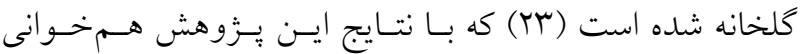

نقش اسيدهاى آمينه در فيزيولوزى رشد، توسعه و تسريع رشــ رويشى گياهان (YY) توجيـهـ كنــده افـزايش وزن گوجـهـفرنحى

اثر برهم كنش اسيدآمينه و اسيدهيوميك بر وزن تازه و خشك ريشه

وزن تازه و خشكى ريشه روندى كاملاً مشـابه از برداشـتهــاى اول و دوم داشت و در هـر دو غلظـت اسـيدآمينه و در هـر دو

غلظت اسيدهيوميك بيشترين مقدار را نشان داد (شكل V). بهطور كلى، كاربرد اسيدهيوميك همـراه بـا اسـيدهاى آمينـه باعث افزايش وزن خشك ريشه شـــ. تـأثير اسـيد هيوميـى در تحريك رشد ريشه بيشتر بـهدليـل دسترسـى بيشـتر بـه عناصـر غذايى (19) است. همجِنين، تأثير اسـيدهيوميك بـر رشــ گيـاه

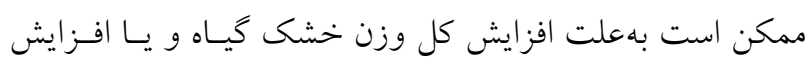
كارايى مصرف كود باشد (Y). بهطورى كـه نـادرى و همكـاران

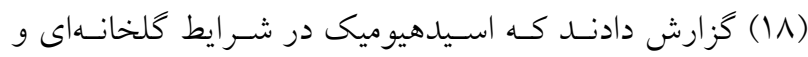
مزرعهاى باعث بهبود رشد كياه از طريق افزايش طـول ريشـه و يا افزايش وزن تازه و خشك ساقه و ريشه مىشود. درحالى كـه كزارش شده كه كاربرد اسيدهيوميك باعث افزايش وزن تـازه و خشك ريشه و شاخساره گوجهفرنخى در شرايط كلخانـه شـده است (T) كه با نتايج اين يزوهش همخوانى داشت. اين نتسايج 

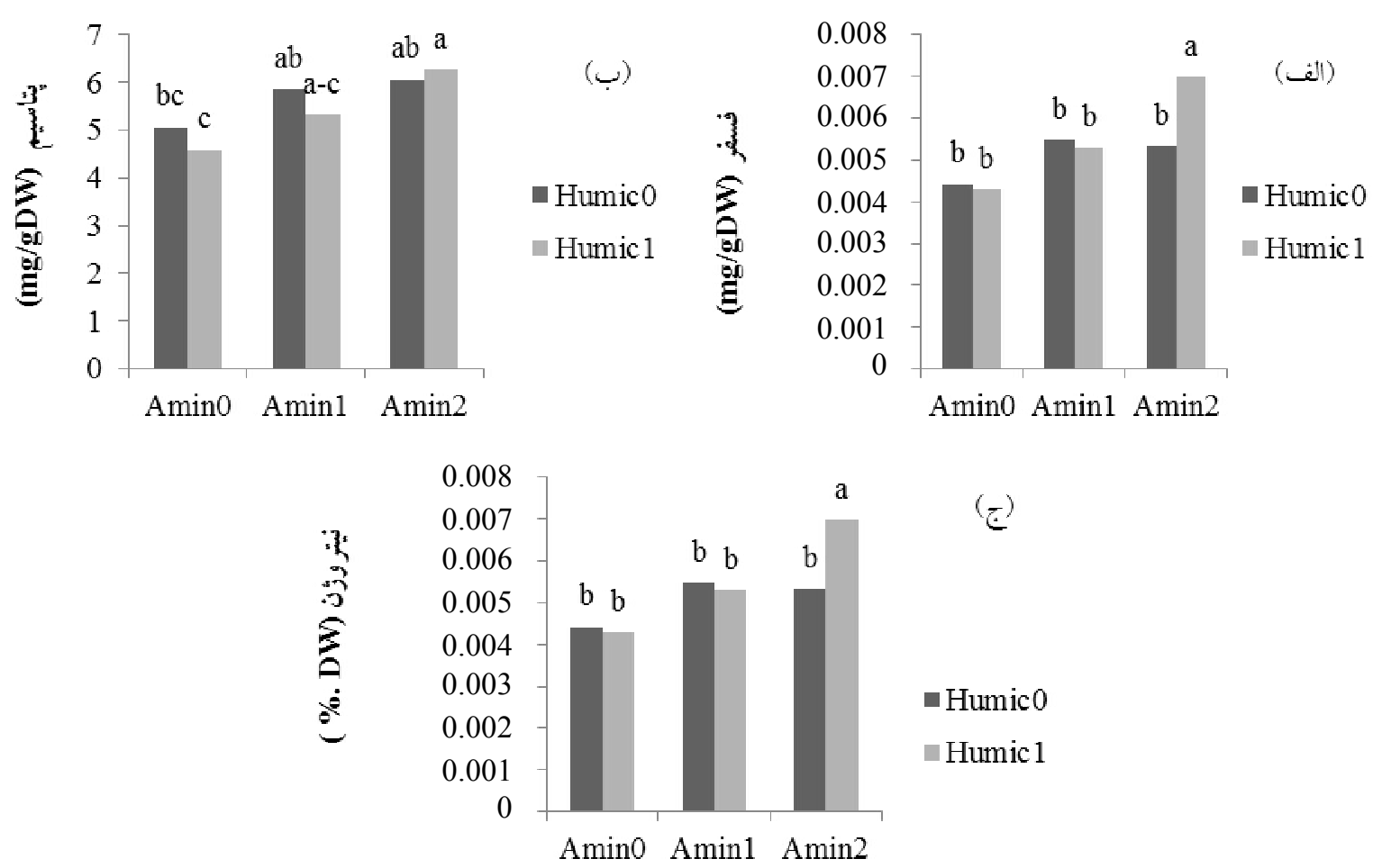

شكل ^ـ اثر برهم كنش اسيدآمينه و اسيدهيوميك بر: الف) فسفر، ب) بتاسيم و ج) نيتروزن ميوه در برداشت دوم (Amin1 شاهد (Amin

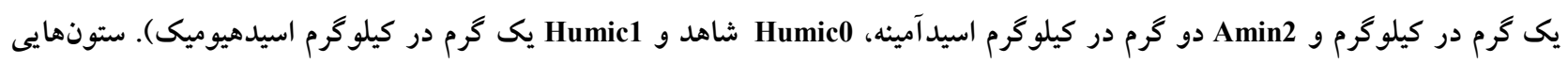

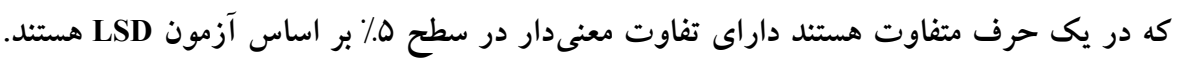

اثر آن بر رشد و جذب عناصر غذايى را بررسى كرد. همجنـين،

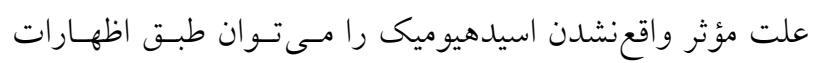

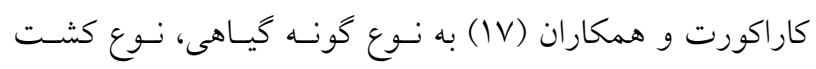

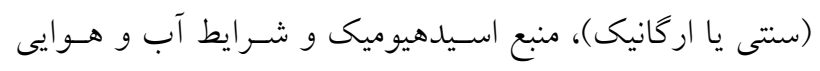

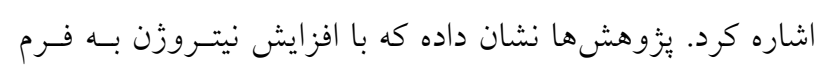

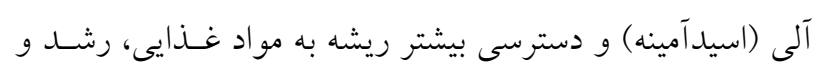

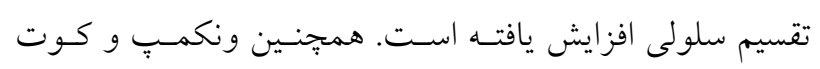

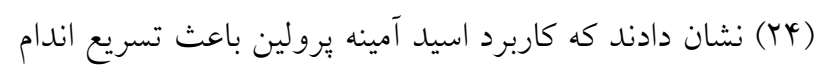

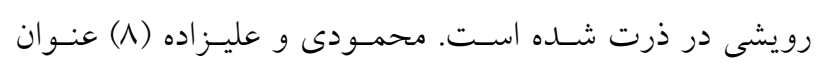

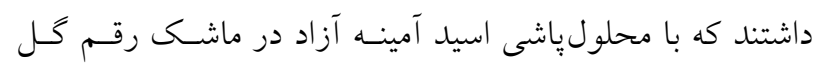

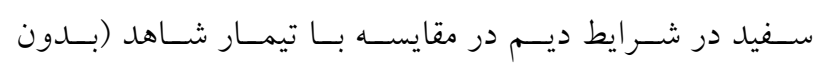

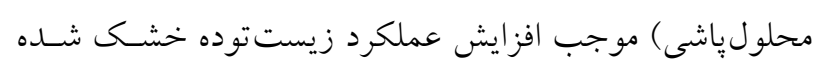

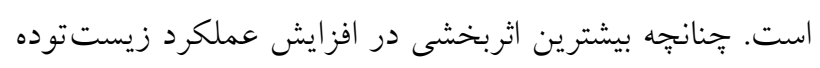
خشك مربوط در سـال اول حاصـل شـده اسـت كـه بـا نتـايج
داشت. بُزوهشها نشان داده كه مــواد اسـيدهيوميك بـهصـورت

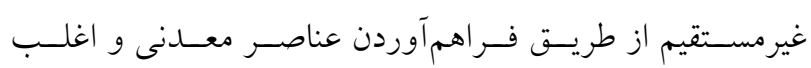

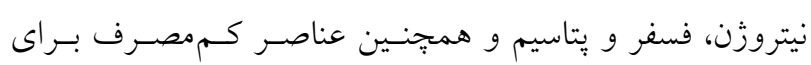

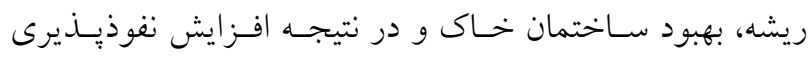

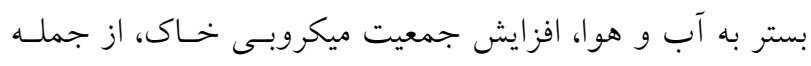

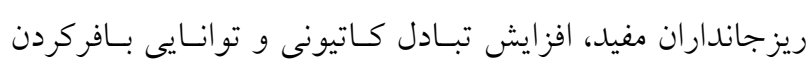

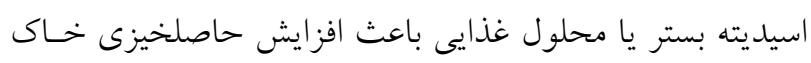
مىشوند (TI). اثر مثبت اسيدهيوميك با غلظت به كار برده شـاهد

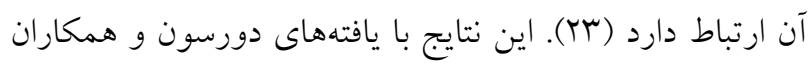

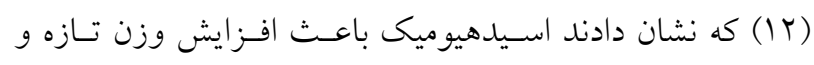

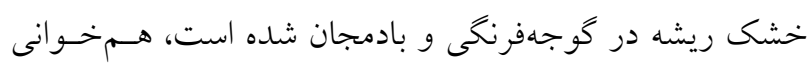

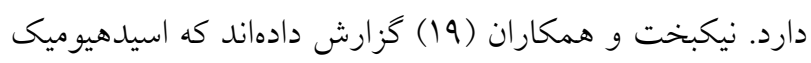

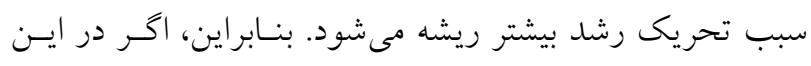

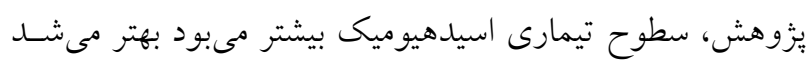


كاهش مقاومت روزنهاى (افزايش هــايت روزنـهاى) در يِــه

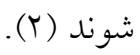

$$
\text { نتيجه كيرى }
$$

بهطور كلى، كاربرد اسيدآمينه همر اه با اسيدهيوميك باعث بهبـود

بسيارى از صفات رشد و فيزيولوزيك كوجهفرنكى شد. بـهنظـر

مىرسد كه استفاده از اين مواد آلى با ميوهدهـى و رسـيدن ميـوه

بايد افزايش يابد تا آثار مثبت نشان دهد زيرا بيشترين اثر مثبـت

در برداشت اول و در مرحله رشد نارنجى و صورتى ديده شد.
آزمايش حاضر هم خوانى داشت. نتايج آزمايش حاضر نيز نشـان داد كه با افزايش غلظت اسيدآمينه، جذب يون يتاسيم نسبت بـه شاهد افزايش يافته است. گزارششده است كه كاربرد اسيدآمينه باعـث افـزايش هــايت مزوفيلسى در گيـاه يسـته شـــه اسـت.

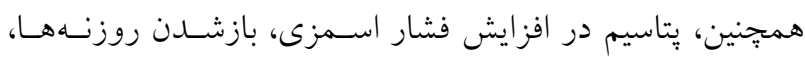
افزايش هدايت مزوفيلى، فتوسنتز بيشتر و عملكــرد بهتـر نقـش دارد. با توجه به نتايج ساير يزووهشخران، بـهنظـر مسىرسـد كـهـ كاربرد تيمار اسيدآمينهاى بهعلاوه سه عنصر ضـرورى نيتـروزن، فسفر و پيتاسيم با تأثير مثبت بر عملكرد گيـاه مسىتواننــ باعـث

\section{منابع مورد استفاده}

ا. ت تدين، م. س.، غ. معافيوريان، و ن. مفتون آزاد. سوها. بررسى اثر تركيبات آمينواسيدى، فولويك اسيد و استروئيدى در انخور ديم

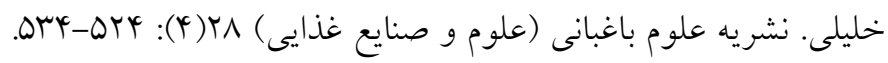

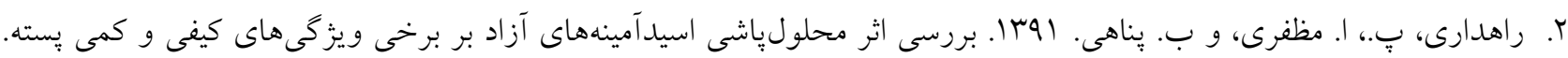

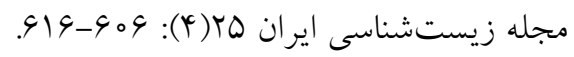

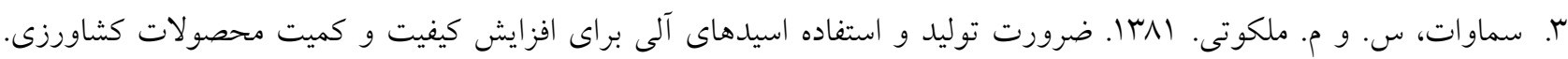
انتشارات سنا، تهران، Or صفحه.

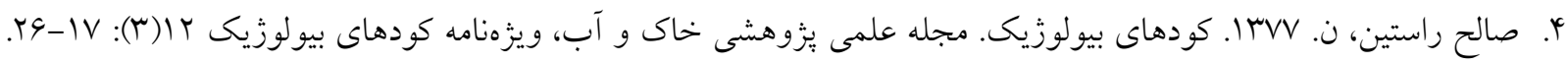

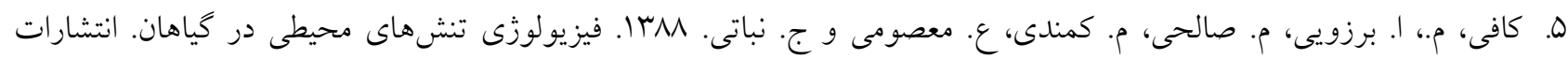

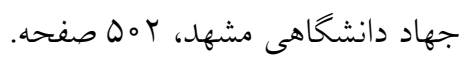

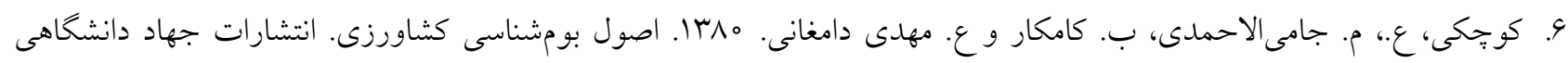
مشهه،

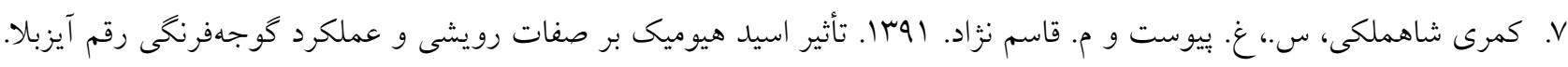

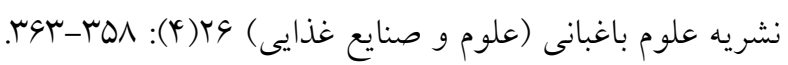

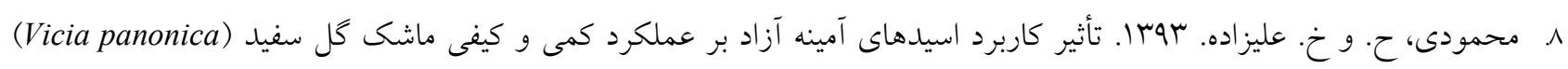

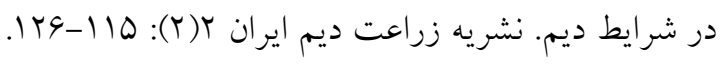

9. Arancon, N.Q., C.A. Edwards, S. Lee and R. Byrne. 2006. Effects of humic acids from vermicomposts on plant growth. Eur. J. Soil Biol. 42: S65-S69.

10. Al-Said, M.A. and A.M. Kamal. 2008. Effect of folair spray with folic acid and some amino acids on flowering yield and quality of sweet pepper. J. Agric. Sci. Mansoura Univ. 33(10): 7403-7412.

11. Cimrin, M.K. and I. Yilmaz. 2005. Humic acid application to lettuce do not improve yield but do improve phosphorus availability. Acta Agric. Scand., Sec. B- Plant Soil Sci. 55(1): 58-63.

12. Dursun, A., I. Guver and M. Turan. 1999. Macro and micro nutrient contents of tomato (Lycopersicon esculentum Mill) and eggplant (Solanum melongena var. Esculentum) seedlings and their effects on seedling growth in relation to humic acid application. PP. 229-232. In: Anac, D. and P. Martin-Prevel (Eds.), Improved Crop Quality by Nutrient Management, Developments in Plant and Soil Sciences, Vol. 86, Springer, Dordrecht. 
13. David, P.P., P.V. Nelson and D.C. Sanders. 1994. A humic acid improves growth of tomato seedling in solution culture. J. Plant. Nutr. 17(1): 173-184.

14. Estan, M.T., M.M. Martinez-Rodriguez, F. Perez-Alfocea and T.J.M.C. Boalrin. 2005. Grafting raises the salt tolerance of tomato through limiting the transport of sodium and chloride to the shoot. J. Exp. Bot. 56: 703-712.

15. Fawzy, Z.F., M.A. El-Nemr and S.A. Saleh. 2007. Influence of levels and methods of potassium fertilizer application on growth and yield of eggplant. J. Appl. Sci. Res. 3(1): 42-49.

16. Faten, S., A.M. Ashaheen, A.A. Ahmed and A.R. Mahmoud. 2010. Effect of foliar application of amino acids as antioxidants on growth, yield and characteristics of squash. Res. J. Agric. Biol. Sci. 6(5): 583-588.

17. Karakurt, Y., H. Unlu, H. Unlu and H. Padem. 2009. The influence of foliar and soil fertilization of humic acid on yield and quality of pepper. Acta Agric. Scand., Sec. B- Soil Plant Sci. 59(3): 233-237.

18. Nardi, S., D. Pizzeghello, A. Muscolo and A. Vianello. 2002. Physiological effects of humic substances on higher plants. Soil Biol. Biochem. 34: 1527-1536.

19. Nikbakht, A., M. Kafi, M. Babalar, Y. Ping Xia, A. Luo and N. Etemadi. 2008. Effect of humic acid on plant growth, nutrient uptake, and postharvest life of gerbera. J. Plant Nutr. 31(12): 2155-2167.

20. Raeisi, M., L. Farahani and M. Palashi. 2014. Changes of qualitative and quantitative properties of radish (Raphanus sativus L.) under foliar spraying through amino acid. Int. J. Biosci. 4(1): 463-468.

21. Sharif, M., R.A. Khattak and M.S. Sarir. 2002. Effect of different levels of lignitic coal drived humic acid on growth of maize plants. Commun. Soil Sci. Plant Anal. 33(19820): 3567-3580.

22. Tejada, M. and J.L. Gonzalez. 2003. Influence of foliar fertilization with amino acids and humic acids on productivity and quality of asparagus. Biol. Agric. Hort. 7(21): 277-291.

23. Turkmen, O., A. Dursun, M. Turan and C. Erdinc. 2004. Calcium and humic acid affect seed germination, growth, and nutrient content of tomato (Lycopersicon esculentum L.) seedlings under saline soil conditions. Acta Agric. Scand., Sec. B- Soil Plant Sci. 54(3): 168-174.

24. Venecamp, J.H. and J.T.M. Koot. 1988. Alterations of free amide and amino acid contents during the development of maize plants (Zea mays L.). Ann. Bot. 62: 589-596. 


\title{
The Effect of Humic Acid and Amino Acid Organic Fertilizers on Growth of Greenhouse Tomato Fruits Harvested at Four Growth Stages
}

\author{
M. Haghighi ${ }^{1 *}$ and H. Najafi ${ }^{1}$
}

(Received: 24 April 2018; Accepted: 9 January 2019)

\begin{abstract}
Due to ever increasing greenhouse cultures, using organic fertilizers for enhancing healthy products is necessary. To investigate the effect of two types of these fertilizers on tomato, in a factorial experiment, based on completely randomized design with 3 replications, with 2 pots in each replication, $0 \mathrm{~g} / \mathrm{kg}$ humic acid (Humic0) and $1 \mathrm{~g} / \mathrm{kg}$ (Humic1) and amino acid at 3 levels of $0 \mathrm{~g} / \mathrm{kg}$ (Amin0), $1 \mathrm{~g} / \mathrm{kg}$ (Amin1) and $2 \mathrm{~g} / \mathrm{kg}$ (Amin2), were fertigated once every 10-day. Fruit characteristics at first and second harvests in green, orange, pink and red phases were studied. Results showed that fruit dry weight was less affected by humic acid and amino acid than fruit fresh weight, especially in green and orange phases. In pink and red phases, in the first harvest, fruit dry weight was increased with amino1 and amino2, in both concentrations of humic acid, as compared with control. Amin1 and humic1 had the highest total soluble solids. Fruit phosphorus concentration in humic1 and amin2 was the highest. Potassium concentrations in amino1 and amino2 in both humic acid concentrations were higher than control. Nitrogen concentration in humic1 and amin2 was increased. Therefore, it is recommended that greater amount of these fertilizers or more application times, be used in nutrient solution of tomato at fruit ripening stage and first harvest. Since using these fertilizers is more effective on fresh weight than on dry weight, it is recommended to use them for fresh tomato consumption than for processing tomato for paste.
\end{abstract}

Keywords: Nutrient uptake, Fruit diameter, Organic fertilizer, Organic product.

1. Dept. of Hort., College of Agric., Isfahan Univ. of Technol., Isfahan, Iran.

* Corresponding Author, Email: mhaghighi@iut.ac.ir 